\title{
Bilgi Politikası Konusundaki Uluslararası Çalışmalarda Kütüphane Kurumuna Yaklaşım: Avrupa Birliği Lizbon Stratejisi ile Birleşmiş Milletler Dünya Bilgi Toplumu Zirvesi
}

\author{
Approach to the Institution of Library in International \\ Studies on Information Policy: European Union Lisbon Strategy \\ and the United Nations' World Summit on the Information \\ Society
}

\author{
Bülent YILMAZ* ve Hakan AYDIN**
}

\begin{abstract}
Öz
Bu çalışmada, Bilgi Politikası konusunda gerçekleştirilen uluslararası çalışmalardan Avrupa Birliği Lizbon Stratejisi (AB LS) ile Birleşmiş Milletler Dünya Bilgi Toplumu Zirvesi (BM DBTZ) çalışmalarında kütüphane kurumunun algılanış ve yer alış düzeyi ile niteliğinin değerlendirilmesi amaçlanmıştır. Bu çerçevede, konunun önce kuramsal çerçevesi çizilmiş, daha sonra konu ile ilgili temel belgeler olarak; "AB Lizbon Stratejisi" belgeleri ile BM DBTZ belgelerinden "ilkeler Bildirgesi", "Eylem Planı", "Tunus Taahhüdü", "Bilgi Toplumu için Tunus Gündemi" ve "BM DBTZ Hedefleri: Bir Dönem Ortası Değerlendirme" belgeleri irdelenmiştir.

Araştırma sonucunda, $A B L S$ çalışmalarında Bilgi ve Iletişim Teknolojileri (BiT) alt yapısı ile kütüphane kurumununilişkilendirildiği belirlenmiştir. BM DBTZ çalışmalarında ise; kütüphanelerin bilgi toplumuna dönüşümün etkin araçları arasında görüldüğü; hükümetlerin, uluslararası kuruluşların, özel sektörün ve sivil toplumun politika ve tedbirlerinde kütüphane kurumuna Bilgi Toplumunun bir bileşeni olarak yer vermeleri gereği vurgulanmıştır. Bu bağlamda çalışmada, ulusal düzeydeki e-stratejilerde ve kalkınma politikalarında kütüphane kurumuna bilgi toplumunun bir bileşeni olarak bilgi politikaları kapsamında yer verilmesi önerilmiştir.
\end{abstract}

Anahtar sözcükler: Avrupa Birliği Lizbon Stratejisi, Birleşmiş Milletler Dünya Bilgi Toplumu Zirvesi, Bilgi toplumu, Bilgi politikası, Kütüphane

\section{Abstract}

In this study, it is taken as a goal to evaluate the approach to the Institution of Library in European Union Lisbon Strategy (EU LS) and the United Nations' World Summit on the information society (WSIS) studies. Within this scope, firstly the conceptual frame of the issue was drawn up and then the basic strategy documen, in relation to the subject and later on, "the EU LS Lisbon

* Prof. Dr., Hacettepe Üniversitesi Bilgi ve Belge Yönetimi Bölümü, Beytepe, Ankara. (byilmaz@hacettepe.edu.tr)
** Doktora öğrencisi, Hacettepe Üniversitesi Bilgi ve Belge Yönetimi Bölümü, Beytepe, Ankara. (haydin@kkk.tsk.tr) 
Strategy " documents, together with UN DBTZ "Declaration of Principles", "Action Plan ", "Tunis Commitment", "Tunis Agenda for the Information Society" and "UN DBTZ Targets: A Mid-Term Review" were examined.

It was found out that in EU LS studies the Information and Communication Technology (ICT) infrastructure was associated with the institution of library.and ilt wasfurthermore figured out in WSIS studies that the institution of library was seen among the effective tools of Information Society, governments, international organizations, private sector and civil society. Conclusively, it was suggested that the institution of library should be taken into account in national e-strategies and development policies -within the scope of information policies.

Keywords: European Union Lisbon Strategy, United Nations' World Summit on the Information Society, Information policy, Information society, library

\section{Giriş}

Uygarlık tarihi incelendiğinde toplumsal değişimin tarım toplumundan sanayi toplumuna, sanayi toplumundan da bilgi toplumuna doğru değiştiği bilinmektedir. Bu dönemlerin hepsinde bilginin önemli olduğu ancak, bir güç olarak en çok ön plana çıktığı dönemin bilgi toplumu aşaması olduğu söylenebilir. Bilgi politikaları, bilgi toplumlarının oluşmasında bilginin toplumsallaşmasına olanak sağlayan önemli işleve sahiptir.

Kütüphane kurumu bilginin toplandığı, saklandığı, hizmete sunulduğu, toplumun bilgi gereksinimini karşılama amacına sahip, odağında bilgi bulunan kültürel ve toplumsal bir kurumdur. Bilgi toplumunda temel unsurun bilgi, kütüphanelerin ise bilginin toplandığı, saklandığı, hizmete sunulduğu kurumlar olması gibi nedenlerden dolayı bilgi toplumu ile kütüphaneler arasında bilgi, bağlamında doğru orantılı bir ilişki yaratmaktadır.

Bu çalışmada, bilgi politikası konusunda uluslararası nitelikte olan Avrupa Birliği Lizbon Stratejisi (ABLS) ve Birleşmiş Milletler Dünya Bilgi Toplumu Zirvesi (BM DBTZ) çalışmalarında kütüphane kurumuna ilişkin yaklaşımın değerlendirilmesi amaçlanmıştır. Bu çerçevede, konunun önce kuramsal çerçevesi çizilmiş, daha sonra konu ile ilgili olarak; "AB LS Lizbon Stratejisi" belgeleri ile BM DBTZ belgelerinden "Illkeler Bildirgesi", "Eylem Planı", "Tunus Taahhüdü", "Bilgi Toplumu için Tunus Gündemi" ve "BM DBTZ Hedefleri: Bir Dönem Ortası Değerlendirme" dokümanları irdelenmiştir. Avrupa Birliği Lizbon Stratejisi (AB LS) çalışmaları ile Birleşmiş Milletler Dünya Bilgi Toplumu Zirvesi çalışmaları ulusal düzeydeki e-stratejilerde ve kalkınma politikalarına rehberlik edebilecek uluslararası alanda yürütülen bilgi toplumu çalışmalarıdır. Hem AB LS çalışmalarında hem de BM DBTZ çalışmalarında, kütüphanelerin bu toplum aşamasının zorunlu kuruluşları olarak ele alındığı görülmüştür. Bir başka deyişle, son on yıla bakıldığında, bilgi toplumu politikaları açısından uluslararası nitelikte en önemli çalışmaların Lizbon Stratejisi ve Dünya Bilgi Toplumu Zirvesi olduğu söylenebilir. Dolayısıyla, çalışmamız bu belgelere dayandırılmıştır. 


\section{Bilgi Toplumu ve Kütüphane Kurumu}

Bilgi toplumuna giden yol bilgiye sahip olmaktan, bilgiyi üretebilmekten ve kullanabilmekten, bilginin gücünden yaralanmaktan, yani bilgiden geçmektedir. Bilgi çağında artık küreselleşen dünyanın ortak malı olan bilgiye erişemeyen, bilgiyi kullanamayan ve bilgi toplumunun sunduğu avantajlardan yararlanamayan toplumlar sanayi toplumunun ve belki de tarım toplumunun standartlarını yaşamak zorunda kalacaklardır. Bilgi çağında, bir ülke, ürettiği bilgi, kullandığı bilgi, geliştirdiği teknoloji ve gerçekleştirdiği yenilikler ölçüsünde söz sahibi olacaktır. Bilgi toplumu olarak sayabileceğimiz gelişmiş ülkeler ulusal düzeydeki e-stratejilerinde ve politikalarında bilginin gücünden, bilgi ve iletişim teknolojilerinin (BiT) sunduğu fırsatları da kullanarak, halklarının refah ve mutluluğunda yararlanmaktadırlar. Tarım ve Sanayi Toplumlarında "güç" insan ve makine gücünü elinde bulunduranlarda iken, Bilgi Toplumunda "güç", bilginin, yani aklın gücünden yararlananlardadır (Tonta, 1999).

Bilgi Toplumu, genel olarak;

$\diamond$ Toplumsal yaşamın her alanında bilginin geçmişle kıyaslanamayacak kadar fazla ve belirleyici biçimde kullanılması;

$\diamond$ Bilginin üretim hızının öncesine göre anlamlı düzeyde yüksek olması;

$\diamond$ Bilgi ekonomisi olarak adlandırılan ekonomik yapıda hizmetler sektörünün tarım ve sanayinin ötesinde bir paya sahip ve hizmet sektörü içinde de bilgiye dayalı etkinliklerin ağırlıklı olması;

$\diamond \quad$ Özellikle bilgisayar ve İnternette simgelenen ve bilginin, üretim, depolanma ve erişimini niteliksel olarak farklılaştıran bilgi ve iletişim teknolojilerindeki çok hızlı ve yapısal değişim ile ifade edilebilir (Yılmaz, 2010).

Bilgi toplumunun en önemli sorunlarından birisi ülkeler arasında yaşanan sayısal uçurum tehlikesidir. Sayısal uçurum olarak da ifade edilebilen sayısal bölünme kavramı; değişik coğrafi alanlarda sosyo-ekonomik koşullar bakımından farklılık gösteren ticari işletmeler ve bireylerin, BiT'e erişim imkânı ile İnternet kullanım amacına yönelik geniş bir yelpazeyi kapsamaktadır (Telekomünikasyon Kurumu, 2002).

Aşağıda, bir anlamda dünyada bilgi toplumu politikaları ile yakından ilgili bir olgu olan sayısal uçurumu ortaya koyan tabloda (Tablo I) dört grup ülke, 2002 yılı ile 2008 yılları itibariyle BiT kalkınma endekslerine göre karşılaştırılmaktadır. 
Tablo I. Gelişmiş Ülkeler ile Gelişmekte Olan Ülkeler Arasındaki

Sayısal Uçurum (2002-2008)

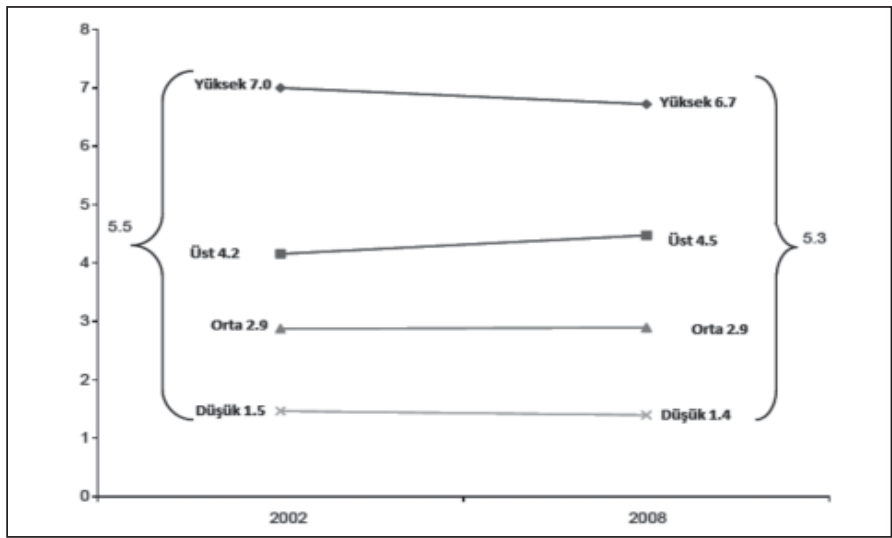

Kaynak: International Telecommunication Union [ITU], 2010

Tablo I incelendiğinde, söz konusu ülkeler arasındaki sayısal uçurumun devam ettiği; ancak bu farkın 2002 yılı ile 2008 yılları arasındaki altı yıl içinde belirli ölçüde azaldığı söylenebilir. Sayısal bölünmenin ölçülmesinde, haberleşme altyapılarına ilave olarak kullanılan en önemli göstergeler arasında, "bilgisayar sayısı", "TV", "mobil telefonlar" ve diğer teknolojiler üzerinden sağlanabilen "alternatif erişim yöntemleri" ve "internet erişimi miktarı" bulunmaktadır (Telekomünikasyon Kurumu, 2002).

Aşağıda yer alan Tablo II günümüz bilgi toplumu ve bilgi politikalarının en önemli olgusu sayılan İnternet kullanımının dünyadaki durumuna ilişkin veriler sunmaktadır.

Tablo II. Dünya Nüfus ve İnternet İstatistikleri (2010)

\begin{tabular}{lrcrc}
\hline Dünya Bölgeleri & Nüfus (2010) & $\begin{array}{c}\text { Internet } \\
\text { Kullanıcıları (2000) }\end{array}$ & $\begin{array}{c}\text { Internet } \\
\text { Kullanıcıları (2010) }\end{array}$ & $\begin{array}{c}\text { Büyüme (\%) } \\
\mathbf{2 0 0 0 - 2 0 1 0}\end{array}$ \\
\hline Afrika & 1013779050 & 4514400 & 110931700 & 2357.3 \\
\hline Asya & 3834792852 & 114304000 & 825094396 & 621.8 \\
\hline Avrupa & 813319511 & 105096093 & 475069448 & 352 \\
\hline Orta Doğu & 212336924 & 3284800 & 63240946 & 1825.3 \\
\hline Kuzey Amerika & 344124450 & 108096800 & 266224500 & 146.3 \\
\hline Latin Amerika / Karayip & 592556972 & 18068919 & 204689836 & 1032.8 \\
\hline Okyanusya / Avustralya & 34700201 & 7620480 & 21263990 & 179 \\
\hline Dünya Toplamı & 6845609960 & 360985492 & 1966514816 & 444.8
\end{tabular}

Kaynak: Internet, 2010 
Tablo II' de 1013779050 nüfusa sahip Afrika'nın 110931 700, 3834792852 nüfusa sahip Asya'nın ise 825094396 İnternet kullanıcısı olduğu görülmektedir. Nüfusuna göre en düşük İnternet kullanımının Afrika'da, en fazla İnternet kullanımının ise Kuzey Amerika'da söz konusu olduğu anlaşılmaktadır. İlgili tablo (Tablo II) verileri Dünya üzerindeki bölgeler arasında sayısal uçurumun varlığını Tablo I verilerini bir başka boyutuyla ve destekleyen biçimde ortaya koymaktadır.

Bilgi toplumundaki gelişmeler, insanın verimliliğinin artmasına, ekonomik gelişme düzeyinin yükselmesine, ayrıca bilimde ve teknolojide yeni gelişmelerin ortaya çıkmasına yol açmaktadır. Daha çok gelişmiş ülkelerin ulaşmış olduğu bir aşama olan bilgi toplumu, gelişmekte olan ülkelerin de kalkınmaları ve küreselleşme sürecine uyum sağlamaları için gereken bir aşama olmuştur (Akçam, 2006).

Kütüphaneler, tarihin her döneminde var olmuşlardır. Kütüphane kurumunun odağında bilgi bulunmaktadır. Bilgi toplumunda öne çıkan ana unsur bilgi, kütüphaneler ise bu bilginin toplandığı, saklandığı, hizmete sunulduğu kurumlardır. Dolayısıyla, bilgi toplumu ile kütüphaneler arasında bilgi bağlamında doğru orantılı bir ilişki bulunmaktadır. Bir ülkedeki kütüphane hizmetleri o ülkenin hem toplumsal hem de ekonomik kalkınmasında önemli bir rol oynar (Çapar, 1987). Kütüphaneler her dönemin çağlar boyu biriken kültürünü her dönemde içlerinde barındırmışlar, bir sonraki döneme aktarmışlardır. Kütüphane, bilgi toplumunun temel kurumlarından birisidir (YIlmaz, 2010).

Bilgi Toplumunda BiT, kütüphane ve bilgi merkezlerini ve hizmetlerini Dünya tarihinde hiç olmadığı kadar etkilemeye başlamıştır. Kütüphane ve bilgi merkezlerine teknolojinin girmesiyle ortaya çıkan önemli değişimler şöyle özetlenebilir (Üstün, 1994):

$\diamond$ Kütüphane ve bilgi merkezlerinde, basılı araç-gereçle birlikte elektronik biçimli bilgiye de geniş ölçüde yer verilmektedir. Buna bağlı olarak kütüphane fiziksel önemini yitirmiş; ancak bilgi hizmeti kavramı yeni bir anlam kazanmıştır. Geleneksel büyük örgütsel yapılanmalar, yerlerini esnek, ufak, ancak hizmet ölçüsü geniş, birçok yaygın erişim noktası bulunan örgütsel birimlere bırakmıştır.

$\diamond \quad$ Yeni bilgi dünyası; kanun, tüzük, yönetmelik ve kurallarla yeni protokol ve anlaşmalar gerektirmeye başlamıştır.

$\diamond$ Yazılım endüstrisi kolunun doğması ve gelişmesine neden olmuştur.

$\diamond$ Çevrimiçi kataloglar, çevrimiçi tarama, elektronik yayınclık gibi olanaklarla seçimli bilgi hizmetleri verilerek, bilgi arzı ve bilgi talebi öğelerinin birbirine yaklaşması sağlanmaktadır

$\diamond$ Kullanıcının ya da belgelerin dolaşması yerine bilgisayar ve iletişim teknolojisinden yararlanılarak bilgi dolaşımına önem verilmekte, kullanıcının masasına kadar ulaşılmaktadır. Ancak bu arada kullanıcının da belirli bir donanıma sahip olması gerekecek, bilgi ile ilgili bazı ücret ödemeleri dışında ayrıca bir parasal gider söz konusu olabilecektir. 
$\diamond \quad$ Kütüphanelerde işbirliği standartlaşma ve kaynak paylaşımı ilkeleri yeni bir anlam kazanmakta, geleneksel kütüphane kaynakları örgütü, bilgi örgütü biçimine dönüşmekte, dizinleme, kavramlar listesi (thesaurus) gibi kavramlarla bu alanlardaki çalışmalar önem kazanmaktadır.

Bilgi politikasının saptanması, planlaması ve uygulanması sürecinde kütüphaneciler geçmişteki başat rollerini kaybederek, bu süreç içerisinde yer alan aktörlerden birisi konumuna düşmüşlerdir (Toplu, 2006).

Bilgi toplumunda kütüphanelerin bilgi kaynaklarında da önemli değişimler olmuştur. Buna örnek olarak elektronik bilgi kaynakları verilebilir. Elektronik bilgi kaynakları, elektronik ortamda üretilen ya da daha sonradan elektronik ortama taşınan bilgi kaynaklarıdır. Bu bilgi kaynakları arasında; kütüphane kataloglarını, elektronik veri tabanlarını, elektronik dergileri, elektronik kitapları, elektronik ansiklopedileri, sözlükleri, biyografileri, elektronik tezleri, elektronik teknik raporları, patentleri ve standartları, elektronik gazeteleri, radyo ve televizyonları, elektronik rehberleri, elektronik müzeleri ve elektronik ses ve görüntü kayıtlarını sayabiliriz.

Gelinen bilgi ve iletişim teknolojisi, hiç kuşkusuz, kütüphanelerin hizmet felsefelerini de bu gelişmelere paralel olarak gözden geçirmelerini gerektirmektedir. Giderek daha fazla bilginin elektronik olarak edinilmesi, elektronik bilgilerin düzenlenmesi, bu bilgilere Internet aracılığıyla erişim sağlanması ve bu bilgilerin korunması kütüphanelerdeki değişimlerden sadece birkaçıdır. Elektronik veri değişimi siparişlerin, faturaların ve isteklerin hızla bir kurumdan diğerine aktarılmasını kolaylaştırmış ve elektronik belge sağlama ve kütüphaneler arası ödünç verme işlemlerinde devrim yaratmıştır (Tonta, 1996). Buradan da anlaşılabileceği gibi, elektronik kütüphaneler kullanıcılarına yeni kolaylıklar sağlamaktadır. Geniş anlamıyla elektronik kütüphane, entelektüel düşünce ürünlerini içeren veri tabanlarından erişim programları aracılığıyla bazı materyallere erişime olanağı sağlayan kütüphaneler olarak tanımlanabilir (Tonta, 1998). Kütüphanelerde 1960'lı yıllarda başlayan ilk bilgisayar uygulamaları, 1970'lerde çevrim içi bilgisayar kataloglarının kullanımının yaygınlaşması ile gelişmiş ve 1980'lerde mikro bilgisayarların ortaya çıkışıyla yeni bir dönem başlamıştır. Aynı yıllarda gelişen CD-ROM teknolojisi, elektronik telekomünikasyon sistemleri ve bilgi ağları, kütüphaneleri gerek yapısal gerekse işlemsel açıdan değişime itmektedir (Uçak, 1995). Kısaca, kütüphaneler günümüzde daha çok elektronik kaynaklara yatırım yapma yoluna gitmeye başlamışlardır.

"Dijital Uçurum" (bölünme) olarak adlandırılan ve teknolojiye/teknolojiye erişim olanaklarına sahip olanlarla olmayanların arasındaki farklar biçiminde ifade edilen eşitsizliğin giderilmesinde kütüphaneler sözü edilen teknolojiyi ücretsiz sağlama işleviyle öne çıkmaktadır. Bir başka deyişle, Bilgi Toplumunda kütüphaneler "Dijital Uçurum"un kapatılmasında rol üstlenmektedirler (Yılmaz, 2010). 
Bilgi toplumu olma yolunda üretilen her bilginin enformasyon haline dönüştürülerek kullanıma sunulmasında kütüphanelerin önemi büyüktür. Kütüphaneler, son on beş yıldır özellikleri, değişkenleri ve dinamikleri belirlenen "Bilgi Toplumu" kavramı ile bilgi toplumunun bilgiye dayalı üretim, üretilen bilginin depolanması ve üretim için yeni bilgi üretilmesi temel ilkeleriyle doğru orantılı kurumlar olarak ön plana çıkmıştır (Rukancı ve Anameriç, 2004).

Dünya Bilgi Toplumu Zirvesi (DBTZ) çalışmalarında kütüphane kurumu hakkında belirtilen hususlar ile ilgili konuların IFLA çalışmalarına da yansıdığı görülmektedir. DBTZ Eylem Planı́na dayalı olarak IFLA'nın hazırladığı "Kütüphaneler ve Dünya Bilgi Toplumu Zirvesi" adlı raporda kütüphanelerle Bilgi Toplumu ilişkisinin belirlenen 11 eylemin tümünde söz konusu olduğu söylenebilir. Bu Plan'da ve dolayısıyla IFLA'nın raporunda Bilgi Toplumu-kütüphaneler ilişkisinin belirginleştiği noktalar şöylece özetlenebilir (Yılmaz, 2010):

$\diamond$ Kütüphaneler, bilgi toplumu için var olan bir ağ ve temel kaynaktır.

$\diamond$ Kütüphaneler, bilgi kullanıcısına yakındır ve dünyanın çoğu yerinde kolaylıkla ulaşılabilir kurumlardır.

$\diamond$ Kütüphaneler, bilgi kaynaklarının içeriğinin değerlendirilmesinde uzmanlaşmış kurumlardır.

$\diamond$ Bilgi Toplumunun tüm olanaklarından yararlanabilmek için herkesin gerekli becerilere ve Bilgi ve İletişim Teknolojileri (BIT) Okuryazarlığına sahip olması gerekir. Kütüphaneler bu becerilerin özellikle eğitimli olmayan, çalışmayan bireylere kazandırımasında çok önemli kurumlardır. Bir başka deyişle, kütüphaneler, e-okuryazarlık anlamına gelen bilgi ve iletişim teknolojileri kullanım becerileri için özel eğitim programları da düzenleyen yerel eğitim ve yetiştirme merkezleridir.

$\diamond \quad$ Kütüphaneler, BiT konusunda uzaktan eğitim gibi programlarının parçası olarak da destek verici kurumlardır.

$\diamond$ Kütüphaneler, eğitim-araştırma kurumları ile bağlantılı ve ağ tabanlı BiT'lerin tasarlanmasını hedefleyen pilot projelerde de işlev yüklenir.

$\diamond$ Kütüphaneler, olumlu İnternet kullanım modellerinin geliştirilmesinde rol oynayabilirler. Bu çerçevede, onlar, gereksinim duyulan bilgiyi sağlarlar. Bunun da ötesinde, kütüphaneler, web tabanlı farklı ve geniş bir materyal çeşitliliği sunar.

$\diamond$ Kütüphaneler, ulusal, bölgesel ve yerel Bilgi Toplumu politikalarının yaşama geçirilmesinde yerel toplulukların temel İnternet erişim merkezleri olarak yer alır.

Bilgi Toplumu-kütüphaneler ilişkisine yönelik somut veriler konunun anlaşılmasında önem taşımaktadır. Bu çerçevede Tablo III'te "“'Dünya'da Kütüphanelerin Durumu”ve Tablo IV'te ise bir başka bilgi merkezi türü olan arşivlerin Dünya'daki durumu sunulmuştur. 
Tablo III. Dünya'da Kütüphanelerin Durumu

\begin{tabular}{|c|c|}
\hline Olkeler & Kütüphaneler \\
\hline Kanada ve ABD & Bilgi (enformasyon) teknolojisinin yeniliklerine uyum sağlıyorlar. \\
\hline Batı Avrupa & Uyum sağlama çabasındalar. \\
\hline Doğu Asya ve Okyanusya & $\begin{array}{l}\text { Gelişen ũlkelerde; iyi kurulmuş bilgi hizmet altyapısı var. } \\
\text { Gelişen ulkelerde; alt yapı geliştirme karar alma aşamasındalar. }\end{array}$ \\
\hline Arap ülkeleri & Politika ve mevzuat eksikligi ile farkındalık sorunları var. \\
\hline Latin Amerika, Karayipler & Bazı çalışmalar var. \\
\hline Afrika & $\begin{array}{l}\text { Ozellikle bōlgenin gelişmesi ve sağlık için kütūphane ve enformasyon } \\
\text { hizmetlerine ihtiyaç var. }\end{array}$ \\
\hline $\begin{array}{l}\text { Doğu Avrupa ve } \\
\text { Bağımsız Devletler Toplulugu }\end{array}$ & Ūlkelere uygun enformasyon politikaları henūz oluşturulmamıştır. \\
\hline Güney Asya & $\begin{array}{l}\text { Bilgi birikimi var, ancak enformasyon araç ve tekniklerinin kullanılması } \\
\text { intiyacı vardır. }\end{array}$ \\
\hline
\end{tabular}

Kaynak: Şan, 2005.

Tablo IV. Dünya'da Arşivlerin Durumu

\begin{tabular}{|c|c|}
\hline Ölkeler & Kütüphaneler \\
\hline Kanada ve ABD & Bilgi (enformasyon) teknolojisinin yeniliklerine uyum sağlıyorlar. \\
\hline Batı Avrupa & Uyum sağlama çabasındalar. \\
\hline Doğu Asya ve Okyanusya & $\begin{array}{l}\text { Gelişen ũlkelerde; iyi kurulmuş bilgi hizmet altyapısı var. } \\
\text { Gelişen ulkelerde; alt yapı geliştirme karar alma aşamasındalar. }\end{array}$ \\
\hline Arap ülkeleri & Politika ve mevzuat eksikligi ile farkındalık sorunları var. \\
\hline Latin Amerika, Karayipler & Bazı çalışmalar var. \\
\hline Afrika & $\begin{array}{l}\text { Ozellikle bōlgenin gelişmesi ve saḡlık için kütüphane ve enformasyon } \\
\text { hizmetlerine ihtiyaç var. }\end{array}$ \\
\hline $\begin{array}{l}\text { Doğu Avrupa ve } \\
\text { Bağımsız Devletler Topluluğu }\end{array}$ & Ūlkelere uygun enformasyon politikaları henūz oluşturulmamıştır. \\
\hline Güney Asya & $\begin{array}{l}\text { Bilgi birikimi var, ancak enformasyon araç ve tekniklerinin kullanılması } \\
\text { ihtiyacı vardır. }\end{array}$ \\
\hline
\end{tabular}

Kaynak: Şan, 2005.

Söz konusu tablolarda yer alan veriler incelendiğinde gelişmiş ülkeler arasında sayabileceğimiz ülkelerde bilgi toplumu özellikleri ile kütüphaneler arasında karşılıklı bir uyum olduğu, ancak bu durumun gelişmekte olan veya az gelişmiş ülkeler içinde var olmadığı görülmektedir. Yani, Dünya üzerinde mevcut bilgi merkezleri olarak kütüphanelerin ve arşivlerin durumu açısından bölgeler arasında ciddi farklılıkların olduğu anlaşılmaktadır. Örneğin kütüphaneler açısından Kanada ve ABD'de BiT yeniliklerine uyum sağlanmış iken Afrika'da daha kütüphane ve enformasyon hizmetlerine gereksinim olduğu anlaşılmaktadır. Latin Amerika ülkelerinde bu yönde bazı çalışmalar söz konusu iken Arap ülkelerinde politika ve mevzuat ile farkındalık olduğu rapor edilmiştir.

Tablo III ve Tablo IV'te yer alan verilere göre, Doğu Avrupa ülkelerinde henüz bir bilgi politikasının olmadığı görülmektedir. Kütüphanelere ilişkin olarak bölgeler arasında görülen farklılığın bir başka önemli bilgi merkezi türü olan arşivler için de büyük ölçüde söz konusu olduğu anlaşılmaktadır. Az gelişmiş bölgelerde arşivler açısından da ciddi sorunların olduğu söylenebilir. Örneğin arşivler açısından Avrupa ve Kuzey 
Amerika'da elektronik kayıtların korunmasında ve sınıflanmasında sorunların olduğu görülmektedir. Bu durum BiT teknolojilerinin kütüphane ve arşivlerde kullanımının önemini yansıtmaktadır.

Tablo V'te dünya üzerinde genel toplam olarak yarım milyondan fazla kütüphanenin olduğu görülmektedir.

Tablo V. Kütüphane Hizmet Noktaları

\begin{tabular}{lrrrrr} 
Bölge & Halk Küt. & Üniversite Küt. & Okul Küt. & Milli Küt. & Toplam \\
\hline Afrika & 797 & 266 & 51 & 15 & 1129 \\
\hline Asya & 37063 & 6909 & 29992 & 66 & 74030 \\
\hline Kuzey Amerika & 20081 & 11460 & 78773 & 50 & 110364 \\
\hline Güney Amerika & 3942 & 17 & - & 32 & 3991 \\
\hline Okyanusya & - & - & 2 & - & 2 \\
\hline Avrupa & 205336 & 10161 & 164436 & 178 & 380111 \\
\hline Toplam & 267219 & 28813 & 273254 & 341 & 569627
\end{tabular}

Kaynak: International Federation of Library Associations and Institutions [IFLA], 2000.

Bu tabloda sunulan 2000 yilına ait verilerde Afrika'da 1129 Asya'da 74 030, Kuzey Amerika'da 110 364, Güney Amerika'da 3 991, Okyanusya ülkelerinde 2 ve Avrupa'da 380111 kütüphanenin bulunduğu görülmektedir. Söz konusu veriler Dünya üzerindeki kütüphane hizmet noktalarının en çok Avrupa'da olduğu, Afrika'daki kütüphane hizmet noktaları rakamının düşündürücü boyutlarda olduğunu ortaya koymaktadır.

Bilgi Toplumunda gücün toplumsal yaşamın her alanında sahip olunan bilgi ile ölçülmesi ve onun geçmişle kıyaslanamayacak kadar fazla ve belirleyici biçimde kullanılması bilgiyi toplayan, saklayan ve hizmete sunan kurumlar olarak kütüphaneleri öne çıkarmıştır.

\section{Bilgi Toplumu ve Bilgi Politikaları}

Bilgi Toplumuna giden yolda bilgi politikaları belirleyici çabaların başında gelir. Bir başka deyişle, Bilgi Toplumuna dönüşümde başarının sağlanması doğru bilgi politikalarının oluşturulması ve yaşama geçirilmesi ile mümkündür. Bu süreçte bilginin toplumsallaşmasına olanak sağlayan "politika" önemli bir işleve sahip olmuştur. Aristoteles politikayı, toplumun halka dair yaptığı tüm etkinlikler olarak tanımlamışırı. Politika, ortak hedeflere ulaşılması için takip edilecek yol ve/veya yöntemdir (Toplu, 2006). Bilgi (information) politikası; “Bilginin üretimi kullanımı, depolanması, iletimi ve sunumunun teşvik edilmesi, edilmemesi veya düzenlenmesini içeren kamu kesimi hukuku, düzenlemeleri ve politikaları bütünüdür (Weingarten, 1989, s.17). Bilgi politikasının ulusal düzeydeki işlevini açıklayan bir yaklaşım, ulusal bilgi stratejisinin bilgi toplumuna geçişi yönetmek için yapılan politikalar olduğunu ifade edilmektedir. Bilgi politikası, bilgi ve iletişim teknolojilerindeki değişimi incelemeye, ülkenin güçlü ve 
zayıf yönlerini değerlendirmeye, sunulan fırsatlara, ülkenin amaçladıkları doğrultusunda toplum ve ekonomi türünün bir vizyona rehberlik etmeye dayandığı belirtilmektedir. Kapsamında toplumsal, örgütsel ve sınai; eğitim, kalite, erişim, bilgi teknolojisi, bilgi pazarı, insan kaynakları, yasa çıkarma ve düzenlemeler yer almaktadır. (Prytherch, 2000, s. 505). Bilgi politikası; belirli bir ülke ya da bölgede, bilgi sağlama ve bilgiye erişimi için yapılan ulusal plandır (Keenan ve Johnston, 2000, s.135).

Kısaca, bilgi politikası, bilginin üretilmesine, yönetilmesine, işlenmesine, erişilmesine ve kullanılmasına öncülük eden birbiri ile ilişkili kanun, yönetmelik, kural ve yargı politikaları ile ilgili uygulamaları düzenleyen politikalardır (McClure ve Dugan, 1996, s.216). Bilgi politikasının içeriğini ise bilgiyi kullanan kişiler, bilgi teknolojileri, bilgi ile ilgili yasal yapı (mevzuat), bilginin maliyeti, bilgi merkezlerinin işbirliği, bilgiye yön veren uzmanlar, ulusal bilgi politikasını gerçekleştirecek kurumların oluşturduğu daha önce de vurgulanmıştı. Duff (2004), bilgi politikasının kapsamını; bilgilenme özgürlüğü, kişisel hakların dokunulmazlığı, veri koruma ve veri güvenliği, resmi sırlar, kütüphaneler ve arşivler, bilimsel, teknik ve tıbbi dokümantasyon, kamu yayınlarının ekonomisi, telif hakları ve entelektüel mülkiyet, ulusal enformasyon altyapısı uluslararası bilgi akışı olarak ele almaktadır.

Yılmaz (2010), bilgi toplumu politikasını; "Bir ülkenin bilgi toplumu olabilmesi ve bu nitelikteki varlığını geliştirip sürdürebilmesi için belirlediği hedeflere ulaşmada izleyeceği yol, yöntem" olarak tanımlamıştır. Bilgi politikalarını bilgi toplumunun en önemli rehberi olarak sayabiliriz. Bilgi politikaları bilim ve teknoloji politikalarından, bilgi çağı ve bilgi toplumu gibi kavramlardan bağımsız olarak düşünülemez. Bilgi teknolojilerini yoğun olarak kullanan ve üreten ülkeler her geçen gün güçlenip egemenlik alanlarını genişletirken, bu alanda gerekli planlamayı ve yatırımı yapmayanlar daha da fakirleşmektedir (Çakın, 2004). Bu noktada Bilgi Toplumu hedefine giden yolda bilgi politikalarından yararlanmanın önemi ön plana çıkmaktadır. Bilgi Politikası oluşturulurken, bilgi odaklı eğitim yapısına, bilgi hizmetleri geliştirecek yeterli finansal ve ekonomik altyapıya, bilgi faaliyetlerini öncelik sırasına koyacak politikalara ihtiyaç duyulmaktadır.

Bilgi politikası oluşturma sürecinde;

$\diamond$ Ülkenin tümünde ya da ulusal kapsamda bütünleşik bilgi hizmetleri ve sistemleri faaliyet planı tasarlanmalı,

$\diamond$ Koordinasyonlu ve bütünleşik bilgi programları başlatılmalı,

$\diamond$ Doğru zaman ve yerde bilgi projeleri yürütülmeli,

$\diamond$ En uygun (optimum) düzeyde bilgi hizmetleri ve sistemleri yürütülmesi gerekmektedir.

$\diamond \quad$ Oluşturulacak bilgi politikası gelişen teknoloji ve şartlara uygun ya da kolayca uyarlanabilen bir yapıya sahip olmalıdır (Montviloff, 1990). 
Montviloff (1990) ulusal bilgi politikalarının dört ana unsura dayandığından söz ederken, bunları;

$\diamond$ Bilgi kaynakları,

$\diamond$ Bilgi hizmetleri,

$\diamond$ Bilgi sistemleri,

$\diamond \quad$ Bilgi altyapısı olarak sıralar ve kütüphane ve arşiv gibi bilgi merkezlerini “Bilgi hizmetleri" unsurunun içinde yer alan kurumlar olarak kabul eder.

McClure ve Jaeger (2008), e-devlet, bilgi yönetimi BiT bilgi politikasının kapsamına eklenebileceğini belirtmiştir. Bilgi politikaları eşzamanlı olarak BiT'lerin konuşlandırılmasına yön vererek, kurumların işleyişini yöneterek ve devlet bilgi faaliyetlerinin parametrelerine karar vererek; bilginin ilişkili olduğu ekonomi, sosyal ve politik birçok sistemi de etkilemektedir. Öte yandan bilgi politikasının kütüphane ve bilgi bilimi, ekonomi, hukuk, politika, bilgisayar bilimleri, sosyoloji ve iletişim gibi birçok akademik disiplinin konusu olduğu vurgulanmıştır. Görüldüğü bilgi politikalarının merkezinde bilgi vardır.

\section{Bilgi Politikaları Konusunda Uluslararası Çalışmalar}

Bilgi politikası konusunda Dünya üzerinde uluslararası kapsamda planlanan ve yürütülen bazı uluslararası çalışmalar genel kapsamları itibariyle şunlardır:

○ Ingiliz Kütüphanesi Çalışmaları (1948): Kütüphaneler arası ödünç verme sistemi ve bilimsel ve teknik enformasyon yayımındaki sorunların giderilmesi etkinlikleri.

$\checkmark$ ABD Weinberg Raporu (1963): ABD Weinberg raporu gerçek anlamda enformasyon politikasının başlangıcı olarak kabul edilmektedir.

○ Sovyetler Birliği Çalışmaları (1960): Devlet Bilimsel ve Teknik Enformasyon Sistemi'nin amacl; bilim ve teknolojideki son gelişmeler ile ilgili kamu kurumları, organizasyonlar ve girişimciler tarafından sağlanan bilgiler ile ulusal ekonominin bilimsel ve teknolojik gelişimini sağlamaktı.

○ Avrupa Topluluğu Çalışmaları (1960): Üye ülkeler arasında enformasyon teknolojilerine dayalı bir ağ yapısının geliştirilmesi yönünde çalışmalar yürütülmüştür.

$\checkmark$ OECD Enformasyon Politikası Grubu Çalışmaları (1964): Ekonomik İşbirliği ve Kalkınma Örgütü (Organisation for Economic Co-operation and Development, OECD) çalışmaları.

○ Avrupa Konseyi Çalışmaları (1968): Avrupa Dokümantasyon ve Bilgi Sistemi (European Documentation and Information System for Education, EUDISED) eğitim için oluşturulmuştur. 
$\diamond \quad$ Uluslararası Atom Enerji Ajansı (UAEA) (1969): Uluslararası Nükleer Bilgi Sistemi (International Nuclear Information System (INIS) oluşturmuşlardır.

$\diamond$ Çeşitli Ülkelerin Enformasyon Politikası Çalışmaları, (1970'li yıllar):

$\diamond \quad$ Federal Almanya Cumhuriyeti'nde Dokümantasyon Enstitüsü (The Institute for Documentation),

$\checkmark$ Fransa'da the Bilimsel ve Teknolojik Bilgi için Bakanlıklararası Misyon (Interministreal Mission for Scientific and Technologial Information, MIDUST),

$\diamond \quad$ Japonya'da Bilim ve Teknoloji Japonya Bilgi Merkezi (The Japan Information Center of Science and Technology, JICST (1971)),

$\checkmark$ Hindistan'da Bilim ve Teknoloji Ulusal Bilgi Sistemi (National Information System for Science and Technology, NISSAT (1977)) kurulmuştur.

$\checkmark$ COMECON Çalışmaları (1970): Karşılıklı Ekonomik Yardımlaşma Konseyi (Council for Mutual Economic Assistance, COMECON) Bilimsel ve Teknik Bilgi Uluslararası Merkezi (International Centre for Scientific and Technical Information, ICSTI)'yı oluşturmuşlardır.

$\diamond$ UNESCO UNISIST, NATIS, GIP Çalışmaları (1971): BM Uluslararası Bilimsel Bilgi Sistemi (UN International Scientific Information System, UNISIST), BM Ulusal Bilimsel Bilgi Sistemi (UN National Scientific Information System, NATIS), BM Genel Bilgi Programı (UN General Information Program, GIP) çalışmaları.

$\diamond$ FAO Çalışmaları (1975): Gıda ve Tarım Örgütü (Food and Agriculture Organization) tarafından Tarım Bilimleri ve Teknolojileri Uluslararası Bilgi Sistemi (International Information Systems for the Agricultural Sciences and Technology, AGRIS) oluşturmuştur. (Toplu, 2006)

Bilgi politikaları konusunda da uluslararası düzeyde çalışmalar yapan en önemli kuruluş olarak UNESCO, eğitim, bilim ve kültür alanlarındaki amaçlarını, kendisine üye olan her devlette kurulan Milli Komisyonlarla gerçekleştirmeye çalışmaktadır (Unesco.org.tr, 2011). Kütüphane hizmetlerinin planlamasında UNESCO'nun öne çıkan çalışmaları şöylece özetlenebilir:

$\diamond$ UNESCO/IFLAişbirliğiile yazokulunun açılması, 1948: Halk kütüphanelerini popüler ve temel eğitim merkezleri haline getirmenin yollarını aramak ve özellikle İkinci Dünya Savaşı sonrası yeniden kalkınmakta olan ülkelerin kütüphane geliştirme problemlerine çözümler getirmek amaçlanmıştır.

$\diamond$ UNESCO MALMÖ Semineri, 1950: Kütüphanecilik bilgisine katkıda bulunmak, kütüphanelerde yetişkinlerin eğitimi programlarının planlanmasına yardıma olmak ve katılanlara UNESCO'nun amaçlarını ve programlarını anlatmak hedeflenmiştir. 
$\checkmark$ UNESCO Bibliyografya Hizmetleri Konferansı, 1950: Her ülkede bibliyografya ve enformasyon hizmetlerinin geliştirilmesini sağlayan bir planlama organizasyonunun kurulması amaçlanmıştır.

$\checkmark$ UNESCO Bölgesel Konferanslar, 1951-1960 Dönemi: Sao Paulo (Brezilya), İbadan (Nijerya), Delhi (Hindistan), Beyrut (Lübnan)'da Halk Kütüphanelerinin geliştirilmesi ile ilgili bölgesel konferanslar düzenlenmiştir.

$\checkmark$ UNESCO Bölgesel Seminerler, 1960-1966 Dönemi: Delhi, Hindistan'da, Mexico City (Mexico), Enugu (Nijerya), Mendoza (Arjantin), Kahire (Mısır), Manila (Filipinler)'de kütüphane hizmetlerinin ülkeler çapında planlanması ile ilgili seminerler düzenlenmiştir.

$\checkmark$ UNESCO Bölgesel Toplantılar, 1966-1974 Dönemi: Bilgi hizmetlerinin planlanması çalışmaları kapsamında Quito (Ekvador), Colombo (Seylan), Kampala (Uganda), Kahire (Mısır)'da UNESCO uzmanları ile gerçekleştirilen bölgesel toplantılar düzenlenmiştir.

$\checkmark$ UNESCO UNISIST, UNESCO NATIS ve UNESCO GIP Çalışmaları, 1974 Sonrası: Bilimsel ve Teknik Enformasyon Alanında Hükümetler arası Iş̧birliği Programı (UNISIST), Ulusal Enformasyon Sistemleri (NATUS), Genel Bilgi Programı (GIP) çalışmaları yürütülmüştür (Çapar, 1987).

1990'I yıllar bilgisayar, internet, veri tabanları gibi büyük hızla gelişen bilgi ve iletişim teknolojilerinin bilgi politikalarını belirlediği ve etkilerinin 2000'li yıllara uzandığı bir dönem olmuştur.

\section{Bulgular ve Değerlendirme}

Bu araştırmaya da konu olan ve 2000 yılında gerçekleştirilen Avrupa Birliği Lizbon Stratejisi (AB LS) çalışmaları ile 2003 ve 2005 yılında yapılan Birleşmiş Milletler Dünya Bilgi Toplumu Zirvesi (BM DBTZ) çalışmaları ulusal düzeydeki e-stratejilerde ve kalkınma politikalarına rehberlik edebilecek uluslararası alanda yürütülen başlıca bilgi toplumu çalışmalarıdır. Bu çalışmalar aşağıda ayrıntııı biçimde ele alınacaktır.

\section{Avrupa Birliği Lizbon Stratejisi (AB LS) Çalışmaları}

Avrupa Birliği Lizbon Stratejisi (ABLS) kapsamında günümüze değin yürütülen ve araştırmamız kapsamında değerlendireceğimiz çalışmalar şunlardır:

$\diamond \quad$ E-Avrupa Girişimini, 1999.

$\checkmark$ Avrupa Birliği Lizbon Stratejisi (AB LS), 2000.

$\checkmark$ E-Avrupa 2002 Eylem Planı, 2000.

$\diamond$ E-Avrupa 2005 Girişimi, 2002.

$\diamond$ i2010: Büyüme ve İstihdam için Avrupa Bilgi Toplumu, 2005.

$\checkmark$ Avrupa 2020 Stratejisi: Akıllı, Sürdürülebilir ve Kapsayıcı Büyüme (Lizbon, 2010). 
1. E-Avrupa Girişimi: Avrupa Konseyi tarafından, 10-11 Aralık 1999 tarihinde Avrupa'yı herkes için gerçek bilgi toplumuna dönüştürmek amacıyla başlatılan girişimdir. E-Avrupa Girişiminin 10 temel amacı aşağıda verilmiştir:

$\diamond$ Avrupa'daki genç nüfusun sayısal çağa hazırlanması,

$\diamond$ Ucuz internet erişimi,

$\diamond \quad$ E-ticaretin hızlandırılması,

$\diamond$ Araştırmacılar ve öğrenciler için hızlı internet,

$\diamond$ Güvenli elektronik erişim için akıllı kartlar,

$\diamond \quad$ Yüksek teknoloji üreten/kullanan KOBi'ler için risk sermayesi,

$\diamond$ Özürlüler için e-Katılım,

$\diamond$ Çevrimiçi sağlık hizmetleri,

$\diamond$ Akıllı ulaşım,

$\diamond$ Çevrimiçi devlet hizmetleri.

2. Avrupa Birliği Lizbon Stratejisi $(A B L S)$ : On beş $A B$ ülkesinin hükümet ve devlet başkanları tarafından 23-24 Mart 2000 tarihlerinde Lizbon'da, Avrupa'nın gelecek on yılda "dünyadaki en rekabetçi ve dinamik bilgi tabanlı ekonomisi" haline gelmesi hedefini ortaya koymak amaçlı bir stratejidir.

3. E-Avrupa 2002 Eylem Planı: Avrupa Konseyi tarafından 19-20 Haziran 2000 tarihlerinde Fieria'dan yapılan "Lizbon Stratejisi" ve "e-Avrupa Girişimi" çerçevesinde kabul edilen plandır. Eylem planının temel başlıkları aşağıdadır:

$\diamond$ Daha ucuz, daha hızlı, daha güvenli internet,

$\diamond$ Daha ucuz ve daha hızlı internet erişimi,

$\diamond$ Araştırmacılar ve öğrenciler için daha hızlı internet,

$\diamond$ Güvenli ağlar ve akıllı kartlar,

$\diamond$ İnsan kaynağına yatırım,

$\diamond$ Avrupa gençliğinin sayısal çağa hazırlanması,

$\diamond$ Bilgi tabanlı ekonomide iş gücü,

$\diamond$ Bilgi tabanlı ekonomiye herkesin katılımı,

$\diamond$ İnternet kullanımının teşvik edilmesi,

$\diamond \quad$ E-Ticaretin hızlandırılması,

$\diamond$ Elektronik devlet: Kamu hizmetlerine elektronik erişim,

$\diamond$ Çevrimiçi sağlık,

$\diamond \quad$ Küresel ağlar için Avrupa sayısal içeriği,

$\diamond \quad$ Akıllı ulaşım sistemleri.

4. E-Avrupa 2005 Girişimi: Avrupa Konseyi tarafından “E-Avrupa 2002 Eylem Planı'ndaki" hedeflerden internet kullanımının, erişim kadar hızlı bir gelişme gösterememesi nedeniyle, Haziran 2002'de, Sevilla'da yapılan toplantıda 2005 
yılında tamamlanması öngörülen hedefleri gerçekleştirmek amacıyla kabul edilmiştir. E-Avrupa 2005 Eylem Planı'nın temel hedefleri şunlardır:

$\diamond$ E-Devlet, e-Eğitim ve e-Sağlık başta olmak üzere modern çevrimiçi hizmetlerin sunumu,

$\diamond$ Dinamik e-Iş ortamının yaratılması ve bunları mümkün kılacak,

$\diamond$ Rekabetçi fiyatlarla yaygın geniş bant erişimi,

$\diamond$ Güvenli bilgi alt yapısı.

5. i2010: Büyüme ve Istihdam için Avrupa Bilgi Toplumu: Stratejisi, Avrupa Birliği "e-Avrupa 2005 Eylem Planının" tamamlanmasının ardından 2000 yılında Lizbon Stratejisinde ortaya koyduğu politikaları da gözden geçirerek kabul edilmiştir. Strateji, İngilizce üç "i" politika önceliğine (Bilgi alanı [Information space], Yenilik ve Yatırım [Innovation and Investment], Kaynaştırma [Inclusion]) dayanmaktadır. Kütüphanelerde bulunan tarihi ve kültürel mirası elektronik ortama taşıyarak toplumun tüm kesimlerine internetten sunmak amacıyla bu strateji kapsamında "Avrupa Sayısal Kütüphanesi" adında bir proje başlatılmıştır.

6. Avrupa 2020 Stratejisi: Akıllı, Sürdürülebilir ve Kapsayıcı Büyüme için Avrupa Stratejisi: Avrupa Birliği ( $\mathrm{AB}$ ) Komisyonu tarafından $A B^{\prime}$ nin yeni ekonomik dönüşüm stratejisini ve 2020 yılı için hedeflerini ortaya koymak maksadıyla 3 Mart 2010 tarihinde açıklanmıştır. Stratejide, AB için birbirini destekleyen üç öncelik belirtilmektedir:

$\checkmark$ Akılı Büyüme: Bilgi ve Yeniliğe dayalı bir ekonomi,

$\diamond$ Sürdürülebilir Büyüme: Daha verimli kaynak kullanan, yeşil ve rekabet edebilir bir ekonomi,

$\diamond$ Kapsayıcı Büyüme: Ekonomik, sosyal ve sınırsal anlamda bütünleşmeyi sağlayan yüksek istihdam ekonomisi.

Lizbon Stratejisi "e-Avrupa 2002 Eylem Planında" kütüphane kurumu ile ilgili olarak "Araştırma ve Yenilik Alanında bir Avrupa Tesis etmek" alt başlığında ele alındığı ve "2001 yılı sonuna kadar araştırma enstitülerini, üniversiteleri, kütüphaneleri ve okulları birbirine bağlayan yüksek hızlı bir ağ oluşturulmalıdır." hedefinin ortaya konduğu görülmektedir. E-Avrupa 2002 Eylem Planı, Haziran 2002'de Eylem Planında yer alan hedeflerin çok büyük bir kısmının başarıyla gerçekleştirilmesiyle sonuçlanmıştır. Bu kapsamda; Avrupa çapında geniş kapsamlı bir internet erişimine kavuşulmuş, internet erişimine sahip hane halkı sayısı üç katına çıkarılmış ve Avrupa dünyadaki en hızlı araştırma ağına sahip olmuştur (Lisbon European Council, 2000).

Lizbon Stratejisi "e-Avrupa 2005 Eylem Planında" kütüphane kurumu ile ilgili olarak "2005 sonuna kadar eğitim ve araştırma amacıyla tüm okullarda ve üniversitelerde geniş bant İnternet bağlantısı sağlanmalıdır. E-eğitimde önemli rol oynayan müzeler, kütüphaneler, arşivler ve benzeri kuruluşlarda da ayrıca geniş bant İnternet bağlantısı sağlanmalıdır." hedefinin ortaya konduğu görülmektedir (Commission of the European Communities, 2002). 


\section{Birleşmiş Milletler Dünya Bilgi Toplumu Zirvesi (BM DBTZ) Çalışmaları}

BM DBTZ çalışmaları, birinci aşaması 10-12 Aralık 2003 tarihlerinde Cenevre'de, ikinci aşaması 16-18 Kasım 2005 tarihlerinde Tunus'ta BM Uluslararası Telekomünikasyon Birliği (ITU) koordinasyonunda, 175 ülkeden 11.000'den fazla katılımcı ile düzenlenmiş olan bir etkinliktir (Bilgi, 2010). DBTZ çalışmalarında;

$\diamond$ DBTZ'nin amacı; “Bizdünyahalklarının temsilcileriolarak 10-12 Aralık2003 tarihinde Cenevre'de Dünya Bilgi Toplumu Zirvesinin birinci aşaması için toplanarak, herkesin bilgiyi ve malumatı üretebileceği, erişebileceği, kullanabileceği ve paylaşabileceği; insan merkezli, kapsayıcı ve kalkınma odaklı bir "Bilgi Toplumu" için ortak arzumuzu ve taahhüdümüzü ilan ediyoruz. Böylece, Insan Hakları Evrensel Beyannamesinde ve Birleşmiş Milletler Sözleşmesinde yer alan ilke ve amaçlar çerçevesinde fertlerin, toplumların ve halkların sürdürülebilir kalkınmalarını sağlama ve yaşam kalitelerini artırma konusunda potansiyellerini tam olarak kullanmaları mümkün olacaktır." olarak,

$\diamond$ Bilgi toplumu olarak sayabileceğimiz gelişmiş ülkeler ile gelişmekte veya az gelişmiş ülkeler arasında yaşanan sayısal uçurum gerçeği; "Bilgi teknolojisi devriminin faydalarının bugün gelişmiş ve gelişmekte olan ülkeler ve toplum katmanları arasında eşit olarak dağılmadığının farkındayız. Bu sayısal uçurumun, özellikle geride bırakılma ve daha da marjinalleşme riski olanlar başta olmak üzere, herkes için sayısal fırsat haline dönüştürmek için elimizden geleni yapmaya kararlıyız" biçiminde,

$\diamond$ Sayısal dayanışmanın önemi; "Kapsamlı bir Bilgi Toplumu inşa etmenin, devlet ile diğer paydaşlar, yani özel sektör, sivil toplum ve uluslararası kuruluşlar arasında yeni dayanışma, ortaklık ve işbirliği türleri gerektirdiğini kabul ediyoruz. Bu bildirgenin, sayısal uçurumun kapatılması ve herkes için uyumlu, adil ve eşitlikçi kalkınma olarak ortaya koyduğu iddialı hedefin bütün paydaşlar açısından güçlü bir kararlılık gerektireceğinin farkındayız. Bunun için herkesi hem ulusal hem uluslar arası düzeyde sayısal dayanışmaya davet ediyoruz" biçiminde ifade edilmiştir (Bilgitoplumu.gov.tr).

DBTZ çalışmalarında zirveye katılan ülkelerin onayı ile kabul edilen belgeler Tablo VI'da sunulmuştur.

Tablo VI. DBTZ'de Kabul Edilen Belgeler

\begin{tabular}{l|l|l}
\hline Sıra no & Belge adı & \multirow{2}{*}{ Zirve Aşaması } \\
\hline & İlkeler Bildirgesi & \multirow{2}{*}{ ''inci Aşama } \\
\hline & Eylem Planı & \multirow{2}{*}{ 2'nci Aşama } \\
\hline & Tunus Taahhüdü & \multicolumn{1}{|l}{ Bilgi Toplumu için Tunus Gündemi } \\
\hline
\end{tabular}

Kaynak: Bilgi, 2010. 
DBTZ'nin I. Aşamasında kabul edilen "ilkeler Bildirgesi" raporunda kütüphane kurumu ile ilgili hususlar Tablo VII'de sunulmuştur.

Tablo VII. BM DBTZ Illkeler Bildirgesinde Kütüphane Kurumu

\begin{tabular}{|c|c|c|}
\hline $\begin{array}{l}\text { Sira } \\
\text { no }\end{array}$ & Alt Başlık & Kütüphane Kurumu ile İlişkilendirme \\
\hline 1. & $\begin{array}{l}\text { - B. Herkes için Bilgi Toplumu:Temel } \\
\text { Prensipler } \\
\text { - 2) Bilgi ve iletişim altyapısı: } \\
\text { Kapsayıcı bir bilgi toplumunun } \\
\text { temeli } \\
\text { - } 23^{\prime} \text { üncü Madde }\end{array}$ & $\begin{array}{l}\text { BIT altyapısının gelişimi için daha fazla özel kesim } \\
\text { yatırımını teşvik etmenin yanı sıra geleneksel } \\
\text { pazar şartlarının elvermediği bölgelerde evrensel } \\
\text { hizmet yükümlülüklerinin karşılanmasına da olanak } \\
\text { sağlayan bir çerçevede, bütün düzeylerde istikrar, } \\
\text { tahmin edilebilirlik ve adil rekabet şartlarının } \\
\text { sağlandığı politikalar geliştirilmeli ve uygulanmalıdır. } \\
\text { Dezavantajlı bölgelerde, postane, okul, kütüphane } \\
\text { ve arşiv gibi yerlerde BiT kamu erişim noktalarının } \\
\text { kurulması altyapı ve Bilgi Toplumu hizmetlerine } \\
\text { evrensel erişimi sağlayacak etkin araçlar olabilir. }\end{array}$ \\
\hline
\end{tabular}

- B. Herkes için Bilgi Toplumu:Temel

2. Prensipler

Kütüphane ve arşivler, müzeler, kültürel koleksiyonlar ve diğer toplum temelli erişim noktaları gibi kamusal kurumlar belgesel kayıtların korunmasını ve bunlara ücretsiz ve adil bir şekilde erişimi sağlayacak şekilde güçlendirilmelidir.

- 26'nci Madde

Öğretmenler, eğitimciler, arşivciler, kütüphaneciler ve

- B. Herkes için Bilgi Toplumu:Temel öğrencilerin yanı sıra içerik oluşturucular, yayıncılar

3.
- 4) Kapasite oluşturma

- 32'nci Madde ve üreticiler, özellikle az gelişmiş ülkelerde, Bilgi Toplumunun gelişmesinde aktif rol oynamalıdır.

Kaynak: Bilgi, 2010.

Tablo VII'de özetlenen "DBTZ Illkeler Bildirgesi" belgesi incelendiğinde kütüphane kurumunun herkes için bilgi toplumu alt başlığı kapsamında ele alındığı, BiT alt yapısının bilgiye erişim ve bilgi toplumu için kapasite oluşturma kavramları ile ilişkilendirildiği görülmektedir. Bu bağlamda kütüphane ve arşiv kurumu herkes için bilgi toplumu yaratmada dezavantajlı kişiler için bilgiye erişimi sağlayan etkin araçlar arasında sayılmaktadır. Yine kütüphane, arşiv gibi kurumlar toplum için bilgiye temel erişim noktaları olarak kabul edilmekte ve bunlara ücretsiz ve adil bir erişimin güçlendirilmesi gerektiğine dikkat çekilmektedir. Kütüphanelere ilişkin ilkelerde yer alan önemli bir belirlemede bu meslek grubunun bilgi toplumunun gelişmesinde etkin rol oynamalarının gereğine yapılan vurgudur.

DBTZ'nin I. Aşamasında kabul edilen "Eylem Bildirgesi" raporunda, bir anlamda, "kütüphane kurumuna yaklaşımı" ortaya koyan kütüphane ile ilişkili hususlar Tablo VIII'de topluca sunulmuştur. 
Tablo VIII. BM DBTZ Eylem Planında Kütüphane Kurumu

\begin{tabular}{lll}
\hline Sıra & Alt Başlık & Kütüphane Kurumu ile Ilişkilendirme \\
no
\end{tabular}

\begin{tabular}{|c|c|c|}
\hline & $\begin{array}{l}\text { - B. Hedefler, Amaçlar } \\
\text { ve Beklenen Çıktılar } \\
\text { - 6'ncı Madde, d fıkrası }\end{array}$ & $\begin{array}{l}\text { Halk kütüphanelerini, kültür merkezlerini, müzeleri, postaneleri ve } \\
\text { arşivleri BiT ile bağlamak. }\end{array}$ \\
\hline 2. & $\begin{array}{l}\text { - C2. Bilgi ve iletişim } \\
\text { altyapısı: Bilgi } \\
\text { Toplumunun temeli } \\
\text { - c Maddesi }\end{array}$ & $\begin{array}{l}\text { Ulusal e-stratejiler bağlamında, bütün okullar, üniversiteler, sağlık } \\
\text { kurumları, kütüphaneler, postaneler, toplum merkezleri, müzeler ve } \\
\text { kamu tarafından erişilebilen diğer kurumlar için gösterge hedefleriyle } \\
\text { uyumlu BiT bağlantıları sağlanmalı ve geliştirilmelidir. }\end{array}$ \\
\hline 3. & $\begin{array}{l}\text { - C3. Bilgi ve malumata } \\
\text { erişim } \\
\text { - d Maddesi }\end{array}$ & $\begin{array}{l}\text { Hükümetler ve diğer paydaşlar, sürdürülebilir çok amaçlı kamu } \\
\text { erişim noktaları kurmalı, vatandaşların değişik kanallardan ucuz veya } \\
\text { ücretsiz şekilde İnternet başta olmak üzere değişik bilgi kaynaklarına } \\
\text { ulaşmasını sağlamalıdır. Bu erişim noktaları, kırsal kesim ve hizmetin } \\
\text { az götürüldüğü bölgelere ağırlık verilerek, mümkün olduğunca } \\
\text { kullanıcılara yardım sağlayacak şekilde, kütüphanelerde, eğitim } \\
\text { kurumlarında, kamu binalarında, postanelerde veya diğer halka açık } \\
\text { yerlerde konuşlandırılmalı, bilginin kullanımı ve paylaşımı teşvik } \\
\text { edilirken fikri haklara saygı ilkesi gözetilmelidir. }\end{array}$ \\
\hline
\end{tabular}
edilirken fikri haklara saygı ilkesi gözetilmelidir.

Ulusal kütüphane stratejilerinin ve mevzuatının gözden geçirilmesi,

4. - C3. Bilgiye erişim

4. - h Maddesi melez kütüphaneler için ihtiyaç konusunda küresel bir anlayışın geliştirilmesi ve dünya çapında kütüphaneler arası işbirliğinin teşviki dâhil olmak üzere Bilgi Toplumuna uygun dijital halk kütüphanesi ve arşiv hizmetleri oluşturulmalı ve desteklenmelidir.

Mevcut kütüphaneler, çok amaçlı toplum merkezleri ve kamu erişim noktalarının bir araç olarak kullanılması suretiyle örneğin kamu yönetimi için kurslar düzenleyerek ve ilgili bütün paydaşların katılımıyla yerel BIT eğitim merkezleri kurularak herkes için e-okuryazarlık becerileri teşvik edilmelidir. Dezavantajı ve korunmasız gruplara özel önem verilmelidir.
5. geliştirme

- c Maddesi
Arşivciler, kütüphaneciler, müzeciler, bilim adamları, öğretmenler, gazeteciler, posta çalışanları gibi bilgi profesyonellerinin eğitim ihtiyaçlarını karşılamak amacıyla BiT'in kullanımına yönelik özel programlar dizayn edilmelidir.
6. geliştirme

- k Maddesi
Kütüphane, arşiv ve müzeler ile diğer kültürel kurumların, geleneksel bilgi de dâhil olmak üzere Bilgi Toplumunda içerik sağlayıcı ve özellikle kayıtlı bilgilere sürekli erişim sağlayıcı rollerini tam olarak oynamaları için ulusal politikalar geliştirilmeli ve buna uygun kanunlar çıkarılmalıdır.

Doğal ve kültürel mirasın korunması ve günümüz kültürünün yaşayan bir parçası olarak erişilebilir kılınması için BiT'in geliştirilmesi ve kullanılması gayretleri desteklenmelidir. Bu sayısal depolarda arşivlenmiş sayısal bilgi ve çoklu ortam (multimedya) içeriğine daimi erişimi güvence altına alan sistemlerin geliştirilmesini ve arşiv, kütüphane ve kültürel koleksiyonların insanlığın hafızası olarak korunmasını da içermelidir.

Kaynak: Bilgi, 2010. 
Tablo VIII'de özetlenen "DBTZ Eylem Planı" kapsamındaki hususlar incelendiğinde; kütüphane kurumunun bilgi toplumu konusundaki bir eylem sürecinde "hedefler, amaçlar", bilgi toplumunun temeli sayılan "bilgi ve iletişim altyapısı", "bilgiye erişim", "kapasite geliştirme" ve "kültürel çeşitlilik" başılıları altında geçtiği görülmektedir. Bir başka deyişle, ilgili eylem planında kütüphane kurumu bilgi toplumu ile hemen hemen tüm başlıklar altında ilişkilendirilmektedir. Bu bağlamda, Eylem Planı'nda ulusal e-stratejiler kapsamında kütüphane kurumuna bilgi ve iletişim altyapısının sağlanmasının gerekliliği vurgulanmakta; kütüphane kurumu bilgi toplumu hedefinde bilgiye erişimde, bilginin kullanılması ve paylaşılmasında etkin araçlar arasında görülmektedir. BIT teknolojilerinin gelişmesiyle kütüphaneler arası işbirliği olanaklarının da artması sonucu dünya çapında kütüphaneler arası işbirliğinin teşvik edildiği, bilgi toplumu hedefine giden yolda elektronik kütüphane ve arşiv hizmetlerinin desteklendiği belirtilmektedir. Ayrıca, planda, kütüphaneler herkes için e-okuryazarlık becerilerinin kazandırılabileceği kurumlar olarak sayılmaktadır. Kütüphanelerin bilgi toplumunda içerik sağlayıcı ve özellikle kayıtlı bilgilere sürekli erişim sağlayıcı kurumlar olarak varsayıldığı, bu kurumların bu rollerini tam olarak oynamaları için ulusal politikalar geliştirmenin ve buna uygun yasalar çıkarmanın öneminin vurgulandığı, kütüphanelerin insanlığın hafızası biçiminde tanımlandığı anlaşılmaktadır. Özellikle, halk kütüphanelerinin, toplum için İnternet açısından "kamu erişim noktaları" olması, dijital kütüphane ve arşivlerin geliştirilmesi, kütüphanelerin toplumun bilgiye erişim kapasitesini artırmada önemli işlevler yüklenebilecekleri, kültürel çeşitliliğin sağlanmasında kütüphanelerin ciddi roller oynaması gerektiği belirlemeleri bilgi toplumu politikası-kütüphane kurumu ilişkisinin planda dile getirilen diğer noktalarıdır.

Burada incelenen uluslar arası çalışmalarda ortaya çıkan yaklaşımlarda kütüphane kurumunun, bilgi toplumu politikasının doğal bir parçası olarak algılanmakta ve kabul edilmekte olduğu rahatlıkla söylenebilir.

DBTZ'nin II. Aşamasında kabul edilen “Bilgi Toplumu için Tunus Gündemi” raporunda kütüphane kurumu ile ilgili hususlar bir önceki tablo yapısıyla Tablo IX'da sunulmuştur.

Tablo IX. BM DBTZ Bilgi Toplumu için Tunus Gündeminde Kütüphane Kurumu

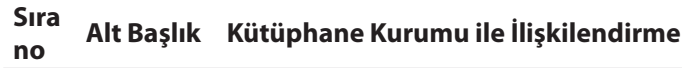

Başta az hizmet alan topluluklar olmak üzere toplulukların bağlanabilirliğini ve BiT okuryazarlığını geliştiren, bilgiye eşit ve serbest erişimi sağlayan kamusal - 90'ıncı hizmet rolü nedeniyle özellikle kütüphanelerin; örgün veya yaygın eğitim, bilim

1. Madde, $\mathrm{k}$ ve yenilikçiliği destekleyen, dijital form dâhil geniş ve çeşitli içeriği barındıran, fıkrası karşılanabilir maliyetlerle, adil, açık erişim sağlayan, geliştirici rollere sahip ve herkese açık ve ücretsiz olan kütüphaneler, arşivler ve müzeler gibi eğitsel, kültürel ve bilimsel kuruluşların desteklenmesi,

2. $93^{\prime}$ üncü
Madde
Tarih ve kültürel bilgimizi gelecek nesillerin faydalanması için dijitalleştirme ile uğraşıyoruz. Kamu ve özel sektörde, teknolojik eskimişlikle baş etmek için bilgiye devamlı erişim ve uzun vadeli korumayı, standart temelli dijital arşivleme ve yenilikçi çözümleri içeren etkin bilgi yönetimi politikalarını teşvik ediyoruz.

Kaynak: Bilgi, 2010. 
Tablo IX'da özetlenen "Bilgi Toplumu için Tunus Gündemi" belgesinde, kütüphane kurumu "az hizmet alan topluluklar olmak üzere toplulukların bağlanabilirliğini ve BiT okuryazarlığını geliştiren, bilgiye eşit ve serbest erişimi sağlayan kamusal hizmet rolü nedeniyle özellikle kütüphaneler; örgün veya yaygın eğitim, bilim ve yenilikçiliği destekleyen, dijital form dâhil geniş ve çeşitli içeriği barındıran, karşılanabilir maliyetlerle, adil, açık erişim sağlayan, geliştirici rollere sahip ve herkese açık eğitsel, kültürel ve bilimsel kuruluşlar" arasında değerlendirilmektedir. Bu nedenle de kütüphaneler, arşivler ve müzeler gibi eğitsel, kültürel ve bilimsel kuruluşların desteklenmesi gerektiği belirtilmektedir. Yine, aynı Belge'de, kütüphane kurumunun özellikle kültürel mirasın korunması, erişimi bağlamında dijitalleştirme olgusu ile ilişkilendirildiği ve öne çıktığı anlaşılmaktadır.

DBTZ'nde bilgi toplumu olma yolunda ülkeler tarafından 2015 yılına kadar tamamlanmak üzere on temel hedef belirlenmiştir. Bu hedeflerden dördüncüsü “halk kütüphanelerini, kültür merkezlerini, müzeleri, postaneleri ve arşivleri BiT ile bağlamak" olarak belirtilen maddedir. Bu hedeflere ilişkin olarak ITU tarafından 2010 yılında “DBTZ Hedefleri: Bir dönem ortası incelemesi“ raporu yayınlanmıştır. Raporda gelişmiş ülkelerdeki kütüphanelerin, müzelerin ve arşivlerin çok büyük bir kısmının genellikle geniş bant hızları ile bağlantı sağladıkları, ancak gelişmekte olan ülkelerde bu durumun henüz gerçekleşmediği belirtilmektedir (ITU, 2010). Ayrıca söz konusu raporda, ABD'de bulunan halk kütüphaneleri ile kütüphanelerde sunulan bilgisayarlar ve internet hizmetine ABD toplumunun \%78'inin ücretsiz erişim sağladığı bilgisi de yer almaktadır.

Bulgularımıza ilişkin genel olarak şunlar söylenebilir:

$\diamond$ Gelişmiş ülkeler arasında sayabileceğimiz ülkelerde bilgi toplumu özellikleri ile kütüphaneler arasında karşılıklı bir uyum olduğu, ancak bu durumun gelişmekte olan ülkeler içinde var olmadığı görülmektedir. Kütüphanelere ilişkin olarak bölgeler arasında görülen farklılığın önemli bir diğer merkezi türü olan arşivler için de büyük ölçüde söz konusu olduğu ve az gelişmiş bölgelerde arşivler açısından ciddi sorunların olduğu söylenebilir.

$\diamond \quad A B$ LS çalışmalarında bilgi toplumu için yapısal reform sürecini hızlandırarak bilgiye dayalı bir ekonomiye geçişin planlandığı, bu kapsamda bilgi toplumu için BIT alt yapısı ile kütüphane kurumunun ilişkilendirildiği görülmektedir.

$\diamond$ BM DBTZ çalışmalarında dünya ülkeleri tarafından herkesin bilgiyi üretebileceği, erişebileceği, kullanabileceği ve paylaşabileceği, insan merkezli, kapsayıcı ve kalkınma odaklı bir "bilgi toplumu" için kütüphane kurumu ile ilgili konulara da yer verilmiştir. Bu kapsamda BM DBTZ çalışmalarında, kütüphaneler genel olarak;

$\diamond$ Bilgi ve iletişim altyapısı,

$\diamond$ Bilgi erişim,

$\diamond$ Toplumun BiT kapasitesini geliştirme,

$\diamond$ Kültürel çeşitlilik, kimlik ve dil çeşitliliği,

$\diamond$ Ulusal hafıza ve dijitalleştirme konuları bağlamında ele alınmıştır. 


\section{Sonuç ve Öneriler}

Çalışmamızın sonuçları kısaca şöyle sıralanabilir:

$\diamond$ Kütüphaneler, "herkes için bilgi toplumu" yaratmada tüm toplumun ancak özellikle de dezavantajlı kişilerin bilgiye erişimlerini sağlayacak etkin araçlar arasında sayılmaktadır.

$\diamond$ Kütüphaneler, toplum için bilgiye erişim noktaları olarak kabul edilmekte ve bunlara ücretsiz ve adil bir erişimin güçlendirilmesi gerektiğine dikkat çekilmektedir.

$\diamond$ Kütüphanecilik meslek grubunun bilgi toplumunun gelişmesinde etkin rol oynamasının gereğine vurgu yapılmaktadır.

$\diamond$ Ulusal e-stratejiler bağlamında kütüphane kurumunun bilgi ve iletişim altyapısının sağlanması ve geliştirilmesinin önemi belirtilmektedir.

$\diamond$ Kütüphaneler, bilgiye erişimde, bilginin kullanılması ve paylaşılmasında etkin araçlar arasında sayılmaktadır.

$\diamond$ Kütüphaneler herkes için e-okuryazarlık becerilerinin kazandırılabileceği dolayısıyla toplumun bilgi erişim kapasitesini artıran kurumlar olarak görülmektedir.

$\diamond$ Kütüphaneler ve arşivler insanlığın belleği olarak tanımlanmaktadır. Kütüphanelerin bu işlevlerini Bilgi Toplumunda dijitalleştirme süreci ile gerçekleştirmesi gerektiği sıkça vurgulanmaktadır.

$\diamond$ Kütüphaneler BiT okur-yazarlığını geliştiren, bilgiye eşit ve serbest erişimi sağlayan ve kamusal hizmet rolü üstlenen kurumlar olarak görülmektedir.

$\diamond$ Kütüphaneler, kültürel çeşitliliğin gerçekleşmesine katkıda bulunan kurumlar olarak kabul edilmektedir.

Kısaca söylemek gerekirse, AB LS çalışmalarında BiT alt yapısı ile kütüphane kurumu güçlü bir biçimde ilişkilendirilmekte, BM DBTZ çalışmalarında ise; kütüphane kurumu bilgi toplumunun etkin araçları arasında görülmekte, hükümetlerin, uluslararası kuruluşların, özel sektörün ve sivil toplumun politika ve tedbirlerinde kütüphane kurumuna Bilgi Toplumunun bir bileşeni olarak yer vermelerinin gereği vurgulanmaktadır.

Ulaşılan bu sonuçlara dayanarak şu öneriler sunulabilir:

$\diamond$ Bilgi Toplumunun bilgi politikaları kapsamında kütüphane kurumunun bilgiye erişim, bilginin kullanımı ve paylaşımında etkin bir araç olduğu politika oluşturucuları ve uygulayıcıları tarafından gözden kaçırılmamalıdır.

$\diamond \quad$ Kütüphane kurumu, politika oluşturucuları ve uygulayıcıları tarafından bilgi toplumunda "Dijital Uçurum"un kapatılması için bilgi politikalarının organik bir parçası olarak görülmelidir. 
$\diamond$ Kütüphaneler, Bilgi Toplumu olma yolunda toplum için bilgiye temel erişim noktaları olarak kabul edilmeli, bilgi politikaları kapsamında kütüphanelerin BiT altyapısı sağlanmalı ve geliştirilmelidir.

$\diamond$ Kütüphanelerin birbirleri ile ve Bilgi Toplumuna geçişe destek veren kültür merkezleri, müzeler gibi diğer bellek kuruluşları ile yüksek hızlı BiT ağı altyapısı bağlantılarının sağlanmalı ve bilgi paylaşım ortamının portal, veri ambarı, veri madenciliği benzeri teknolojiler ile desteklenmelidir. Bilgi politikaları kapsamında kütüphane kurumunun da içinde yer aldığı bu portal sayfalarına kamu kuruluşları ile vatandaşların erişimi sağlanmalıdır.

$\diamond$ Bilgi politikaları kapsamında özellikle BiT hizmetlerinin az gittiği bölgelerde yaşayan vatandaşların bilgi gereksinimleri öncelikle dikkate alınmalı ve herkes için bilgi toplumu anlayışı içinde dezavantajlı bölgelerde e-devlet gibi hizmetlere kütüphane kurumu üzerinden sınırsız ve ücretsiz erişim hizmetleri sunulmalıdır.

$\diamond$ Genelolarak, bilgipolitikalarıkapsamındabilgitoplumuna geçiştekütüphanecilik meslek grubundan akademik ve mesleki örgütü bağlamında yararlanılmalıdır.

$\diamond \quad$ Bilgi politikaları ile kütüphanelerde, elektronik kütüphane katalogları, elektronik veri tabanları, elektronik dergiler, elektronik kitaplar, elektronik ansiklopediler, elektronik sözlükler, elektronik biyografiler, elektronik tezler, elektronik teknik raporlar, elektronik patentler ve standartlar, elektronik gazeteler, elektronik rehberler, elektronik müzeler, elektronik ses ve görüntü kayıtları gibi elektronik bilgi kaynaklarının kullanımı desteklenmelidir.

$\diamond$ Ülke çapında dijital halk kütüphanelerinin sayısı çoğaltılmalı, vatandaşların güncel yayınlara sınırsız ve ücretsiz olarak kolay erişimi sağlanmalıdır. Bu kapsamda kütüphanelerin içerik sağlayıcı özellikleri yasal düzenlemeler ve ekonomik yatırımlar ile geliştirilmelidir.

$\diamond$ Kütüphanelerden vatandaşların e-okuryazarlılığının ve bilgi okuryazarlıığının geliştirilmesinde eğitim kurumu gibi yararlanılmalıdır.

$\diamond \quad$ Kütüphaneler insanlığın belleği olan, bilgiye eşit ve serbest erişimi sağlayan ve kamusal hizmet rolü üstlenen kurumlar olarak görülmeli ve kütüphanelere bilgi politikalarının bir bileşeni olarak gereken önem verilmelidir.

Toplumların geleceğini bilgi ile ilişkilerinin niteliği, bilgi ile ilişkilerinin içerik ve düzeyini ise kütüphane kurumuna bakışları belirleyecektir. Bir ülkenin bilgi toplumu olma yönündeki çabasının en önemli göstergeleri arasında kütüphane kurumuna ilişkin yaklaşım ve uygulamalar olduğu unutulmamalıdır. 


\section{Kaynakça}

Akçam, S. (2006). Avrupa Birliğinde bilgi toplumuna geçiş çalışmaları. 13 Ocak 2011 tarihinde http:// www.tobb.org.tr/.../ab_bilgi_toplumu.pdf adresinden erişildi.

Bilgi toplumu. (2010). 13 Ocak 2011 tarihinde http://www.bilgitoplumu.gov.tr adresinden erişildi.

Commission of the European Communities. (2002). e-Europe 2005: An information society for all . 13 Ocak 2011 tarihinde http://ec.europa.eu/.../eeurope2005_en. Pdf adresinden erişildi.

Çakın, İ. (2004). Müteferrika matbaasının düşündürdükleri ve Avrupa'da basımcılığının etkileri: Gelecek için geçmişi anlamak. Bilgi Dünyası, 5(2), 153-167.

Çapar, B. (1987). Kütüphane hizmetlerinin planlanmasında UNESCO'nun rolü ve Türkiye. Türk Kütüphaneciliği, 1(4), 162-174. 13 Ocak 2011 tarihinde http://tk.kutuphaneci.org.tr/.../2051 adresinden erişildi.

Duff, A. S. (2004). The Past, present, and future of information policy. Information, Communication \& Society, $7(1), 69-87$.

International Federation of Library Associations and Institutions. (2010). Global Library Statistics:1990-2000. 13 Ocak 2011 tarihinde http://www.ifla.org/III/wsis/wsis-stats4pub_v. pdf adresinden erişildi.

International Telecommunication Union. (2010). Measuring the information society. 13 Ocak 2011 tarihinde http://www.itu.int/.../MIS_2010_Summary_E.pdf adresinden erişildi.

International Telecommunication Union. (2010). Monitoring the WSIS targets: A mid-term review. 13 Ocak 2011 tarihinde http://www.itu.int/dms_pub/itu-d/opb/ind/D-IND-WTDR-2010-SUMPDF-.pdf adresinden erişildi.

Internet usage statistics: The Internet big picture world Internet users and population stats. (2010). 13 Ocak 2011 tarihinde http://www.internetworldstats.com/stats.htm adresinden erişildi.

Keenan, S. ve Johnston, C. (Yay. Haz. ). (2000). Concise dictionary of library and information science. (2. bs.). London: Bowker Saur.

Lizbon Stratejisi, bilgi toplumu. (2010). 13 Ocak 2011 tarihinde http://www.bilgitoplumu.gov.tr adresinden erişildi.

Lisbon European Council. (2000). 13 Ocak 2011 tarihinde http://www.consilium.europa.eu/ueDocs/ cms_Data/docs/pressData/en/ec/00100-r1.en0.htm adresinden erişildi.

McClure, C. ve Dugan, R. E. (1996). Libraries and federal information policy. Journal of Academic Librarianship, 22, 214-218.

McClure, C. R. ve Jaeger, P. T. (2008). Government information policy research: Importance, approaches, and realities. Library \& Information Science Research, 30(4), 257-264. doi:10.1016/j. lisr.

Montviloff, V. (1990). National information policies : A handbook on the formulation, approval, implementation, operation of a national policy on information. Paris: United Nations Educational, Scientific and Cultural Organization.

Prytherch, R. (Yay. Haz.). (2005). Harrod's librarians' glossary and reference book (10. bs.). Hampshire: Ashgate Publishing. 
Rukancı, F. ve Anameriç, H. (2004). Bilgi toplumu ve toplumun bilgilenmesinde kütüphanelerin rolü. 13 Ocak 2011 tarihinde http://eprints.rclis.org/.../Bilgi_Toplumu_ve_Toplumun_Bilgilenmesinde. pdf adresinden erişildi.

Şan, M. (2005). Kalkınma planlamasında bilgi yönetimi ve Devlet Planlama Teşkilatı için kurumsal bilgi politikası modeli. 13 Ocak 2011 tarihinde http://www.ekutup.dpt.gov.tr/bilgiyon/sanm/ bilgipol.pdf adresinden erişildi.

Telekomünikasyon Kurumu. (2002). Sayısal Uçurum Sektörel Araştırma ve Stratejiler Dairesi Başkanlığı. 13 Ocak 2011 tarihinde http://www.tk.gov.tr/pdf/Sayisal_Ucurum.pdf adresinden erişildi.

Tonta, Y. (1996). Internet, elektronik kütüphaneler ve bilgi erişim. Türk Kütüphaneciliği, 10(3), 215230.

Tonta, Y. (1998). Elektronik kütüphaneler. Özel Ulak, 1(2), 2-3.

Tonta, Y. (1999). Bilgi toplumu ve bilgi teknolojisi. Türk Kütüphaneciliği, 13(4), 363-375.

Toplu, M. (2006). Ulusaldan evrensele enformasyon politikası : Süreçler, değişimler. H. Odabaş ve H. Anameriç (Yay. Haz.), Bilgi... içinde (ss. 129-166). Ankara: Referans Yayıncılık.

Uçak, N. (1995). Kütüphaneleri etkileyen teknolojik yenilikler ve geleceğin kütüphaneleri. Türk Kütüphaneciliği, 9(1), 49-55.

Unesco.org.tr. (2011). 13 Ocak 2011 tarihinde http://www.unesco.org.tr/ adresinden erişildi.

Üstün, A. (1994). Teknolojik gelişmelerin kütüphane ve bilgi merkezlerine etkisi. Türk Kütüphaneciliği, 8(3), 217-229.

Weingarten, F. W. (1989). Federal information policy development: The Congressional perspective. C. R. McClure, P. Hernon ve H. Relyea (Yay. Haz.), United States government information policies: Views and perspectives içinde (ss. 77-99). Norwood, NJ: Ablex.

Yılmaz, B. (2010). Türkiye'nin bilgi toplumu politikasında kütüphane kurumuna yaklaşım. Bilgi Dünyası, 11(2), 263-289. 